\title{
VIII. On an old method of marking dates on manuscript books
}

\section{Gavin Inglis Esq.}

To cite this article: Gavin Inglis Esq. (1819) VIII. On an old method of marking dates on manuscript books, Philosophical Magazine Series 1, 54:255, 46-48, DOI: $10.1080 / 14786441908652181$

To link to this article: http://dx.doi.org/10.1080/14786441908652181

曲 Published online: 29 Jul 2009.

Submit your article to this journal $₫$

Џ Article views: 2

Q View related articles $\sqsubset$ 
nying the value of any discoveries in nature or in science, because their application to useful purposes may not be immediately obvious. How greatly would the heroes and statesmen of antiquity have despised the labours of that man who devoted his life to investigate the properties of the magnet ! Little could they anticipate that this humble mineral was destined to change the very form and condition of human society in every quarter of the globe. Let us bear in mind, that the magnet was known nearly two thousand years hefore it was applied to any purpose of practical utility. During that time the ocean was a fearful and trackless abyss, and voyages were confined to short excursions along the shore. The wanderings of Ulysses, which took ten years to accomplish, did not exceed in extent and difficulty the voyage from Dublin to London. When magnetic polarity was applied to the aid of navigation, mankind seemed to have acquired a new sense ; guided by this mysterious power, Vasco de Gama and Columbus led the way to the eastern and the western world, and a fresh impulse was given to the buman mind, which had been slumbering for centuries. There is not a country inhabited by man where the influence of this discovery has not been felt; it has been the parent of our naval and commercial greatness, and has obtained for us the commanding rank we hold anong the nations of Europe. The history of the magnet should teach us not to despise any discovery in science becanse its utility cannot be immediately perceived. Some discoveries are unproductive, until the progress of science in a future age directs their application to purposes of eminent utility, Such discoveries may be compared to the acorn, which may remain for a time buried in an arid sóil, until, stimulated by the genial rains of heaven, it strikes its roots into the earth, and springs forth to day-bumble indeed in its first appearance, and slow in its progress to maturity; but destined at length to become a mighty oak, stretching its arms amid the skies; the ornament, the strength, and the glory of the forest. June $21,1819$.

13, 'Tavistock-street, Bedford-square.

\section{On an old Method of marking Dates on Manuscript Buoks. By Gavin IngLis, Esq.}

To Mr. Tilloch.

Dear Sir, - Some time ago a collector of rare and curious volumes brought me an old manuscript Prayer Book, heautifully written on vellum, and partially illuminated, and requested I would do him the fivour to look it over and see if I could trace any thing like a date, or mark by which its age might be ascertained, 
which he said constituted its chief worth, and would stamp it with a greater or less value in proportion to its antiquity. He had shown it to different clergymen, who severally examined its contents, without being able to affix any period, or observing any mark, or character, by which they conld trace the date of its origin, although the year was very pointedly dated at the close of the calendar, but in a manner somewhat characteristic of the age of the church to which it belonged, when every thing was concealed under some mystic symbol, or almost unintelligible hieroglyphical hyperbole.

As the date of this little volume escaped the scrutinizing observation of these learned gentlemen, the same mode of dating may have been adopted in other writings of the same period, and perhaps of much greater importance, and which may also have escaped the researcher's notice, when its identity inight have been of some consequence. Perhaps the decyphering of this may give a key, and lead to others of more interesting import. On this ground, may I trouble you to give it a few minutes' consideration, and if you judge it at all likely to be useful or amusing, have the goodness to give it a comer in your next number of the Philosophical Magazine?

The calendar was written in the regular style, the manuscript of which had been finished on the first day of the second month, one thousand four hundred and fifty-six, veiled under the following mystical dotting, made at the close of the last month in the calendar.

To render it the more obscure, there was neither point nor comma, to divide the numbers, which would have made it somewhat plainer, thus:

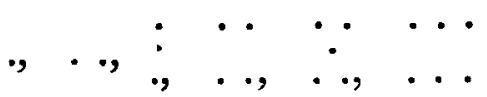

The single dot is the first day, the two horizontal dots mark $t w o$, for the second month. The three dropping or perpendicular dots, in imitation of the old $I$ are only a numerical one. The quatre four, the cinc five, and the six by being laid horizontally denotes the currency of its numbers, and is to be counted $12 \mathbf{3}$

$\therefore:$ i. e. six. Had the six dots been placed thus $\because$ they 46 would have only counted two: had the date been fifty-three, the three must have stood thus $\ldots$ or thus ..., four would 
have been a repetition of the quatre, \&c. Hence the date of the book must be 1 st of the $2 \mathrm{~d}$ month 1456 Ann. Dom.

Strathendry, June 21, 1819.

Yours truly,

\section{Experiments for a new Theory of Vision. By JosEPH READE, M.D.}

Gavin Inglis.

To Mr. Tilloch.

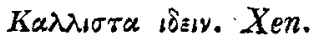

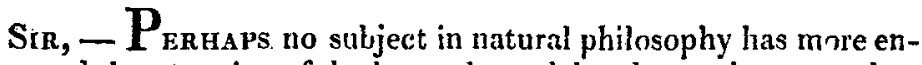
gaged the attention of the learned, or claimed more interest, than that concerning the proper seat of vision. For two bundred years the retinal theory has been maintained, and its difficulties, if not absurdities, softened down by the learned ingenuity of mathematicians and metaphysicians. Well aware that to overturn a theory so universally adopted, and stamper with the seal of antiquity, requires a number of well regulated experiments and legitimate deductions, I now commit my endeavours to the candour of the intelligent reader.

Exp. 1st.-Having often remarked, when examining the eyes of patients, that surrounding oljects, such as a lighted candle, \&c. were painted on the transparent cornea in a beautiful and minute manner, as on the face of a convex speculum, it occurred to me that the mind might receive impressions or ideas from those erect images; and I was the more desirous of bringing this interesting suggestion to the test of experiment, in consequence of the many difficulties attached to the present sistem of vision. I now pasted two narrow strips of black cloth in the shape of the letter 'T, and about three inches in length, on one of the upper panes of a large and well-lighted window. I then requested a gentleman with a large pupil and good sight to seat himself about four or five.feet from the latter, and to fix his eyez steadily on it. Looking into his pupil I perceived the letter $\mathrm{T}$ to be minutely yet distinetly painted by refiexion. I then took a plano-convex lens in my right hand, such as school-boys use for burning-glasses, and held it close to the pupil. On again looking at the corneal image of the letter $\mathrm{T}$, I perceived it enlarged or magniffed in all its dimensions, and the spectator said, he also pereeived it much larger than with the naked eye. On removing the lens a little further from his eye, I perceived the letter on the pupil not only magnified, but surrounded with colours; and now the spectator saw the letter large, confused, and surrounded with colours. So far the phænomena of vision answered exactly to 